\title{
SOME HAEMATOLOGICAL PARAMETERS OF TUBERCULOSIS INFECTED NIGERIANS: A STUDY IN CALABAR - NIGERIA
}

\author{
IFEYINWA M. OKAFOR, ANIEKAN-AUGUSTA O. EYO, ETIM A. OKON AND PATIENCE A. \\ AKPAN
}

(Received 5 September 2012; Revision Accepted 28 January 2013)

\begin{abstract}
Tuberculosis is a major public health problem in Nigeria. Drug resistant tuberculosis is now common place due to poor patient compliance and lack of detection of resistant strains. The occurrence of HIV has been responsible for an increased frequency of tuberculosis. Knowledge of the blood picture in pulmonary tuberculosis, is believed, will be a valuable tool in the management of patients. This study aimed at providing information on haematological changes in pulmonary tuberculosis. A total of 200 subjects were investigated. One hundred of these were pulmonary tuberculosis patients comprising 62 males and 38 females who attended the University of Calabar Teaching Hospital and the Dr. Lawrence Henshaw Memorial Hospital (Infectious Diseases Hospital), Calabar, Cross River State; while the remaining 100 were non-pulmonary tuberculosis subjects comprising 50 males and 50 females who served as control subjects. Standard techniques were used for the assays. Routine haematological analyses were carried out which included Packed Cell Volume, Haemoglobin concentration, Mean Cell Volume, Mean Cell Haemoglobin, Erythrocyte Sedimentation Rate, Platelet and Total White Blood Cell counts. Age and gender were also evaluated in the enrolled subjects. Results showed significantly lower values $(\mathrm{p}<0.05)$ for Packed cell volume, haemoglobin concentration and mean cell haemoglobin concentration in pulmonary tuberculosis patients than in control subjects while mean cell volume and erythrocyte sedimentation rate showed significantly higher values in pulmonary tuberculosis patients than in control subjects. Packed cell volume, Haemoglobin concentration, Mean Cell Volume, Mean Cell Haemoglobin, and Erythrocyte Sedimentation Rate of pulmonary tuberculosis patients co-infected with HIV were significantly affected $(p<0.05)$. The highest prevalence rate of infection $(60 \%)$ occurred in the age group (10 - 30) years. In conclusion, the study showed that tuberculosis had significant effects on the haematological parameters analysed which were in turn aggravated in co-infection with HIV.
\end{abstract}

KEYWORDS: Pulmonary, Tuberculosis, haematological variables, HIV co-infection.

\section{INTRODUCTION}

Tuberculosis (TB) is one of the most important infectious diseases in the world because of its high global prevalence, chronic debilitating characteristic and heavy attack rate on the wage earning community (Nwankwo et al., 2005). It is a chronic disease caused by a group of five closely related species which form the Mycobacterium tuberculosis complex. They include $M$. tuberculosis, $M$. bovis, $M$. africanum, $M$. microfti and $M$. canetti (Iseman, 2000). Mycobacterium tuberculosis is the etiologic agent of a vast majority of tuberculosis. Pulmonary tuberculosis (PTB) is a lower respiratory tract infection initiated by the deposition of Mycobacterium tuberculosis (MTB), contained in aerosol droplets, onto lung alveolar surfaces within 4 - 12 weeks of settling
(Snider et al., 1994). Tuberculosis can remain in an inactive (dormant) state for years without causing symptoms or spreading to other people. When the immune system of a patient with dormant $T B$ is weakened, the TB can become active (reactivate) and cause infection in the lungs or other parts of the body (Iseman, 2008). hThe active disease is characterized by a protracted cough lasting up to 2 weeks or more, fatigue, loss of weight and appetite, fever, night sweats, chest pain and shortness of breath. (Kabir et al., 2010). Haemoptysis, secondary infection by fungi and permanent lung damage are few of the complications of PTB (Fraser, 1993).Tuberculosis is transmitted from person to person through the air by infected droplet nuclei, $1-5 \mu \mathrm{m}$ in diameter that contain the Mycobacterium tuberculosis complex (Edward and Kirk-

Ifeyinwa M. Okafor, Department of Medical Laboratory Science, Faculty of Allied Medical Sciences, University of Calabar, Calabar, Cross River State, Nigeria.

Aniekan-Augusta O. Eyo, Department of Medical Laboratory Science, Faculty of Allied Medical Sciences, University of Calabar, Calabar, Cross River State, Nigeria.

Etim A. Okon, Dr. Lawrence Henshaw Memorial Hospital (Infectious Disease Hospital), Calabar, Cross River State.

Patience A. Akpan, Department of Medical Laboratory Science, Faculty of Allied Medical Sciences, University of Calabar, Calabar, Cross River State, Nigeria. 
Patrick, 1986). The risk factors for acquiring TB include close-contact situations (overcrowding), malnutrition and certain diseases (example diabetes, cancer and HIV) which lower immunity and occupations (example health care workers) (CDC, 2010). According to the World Health Organization (WHO) worldwide prevalence of TB, nearly 2 billion, one third of the world's population (about $32 \%$ ) have TB (WHO, 2010). The body had estimated that between 2000 and 2020 nearly one billion people would be infected, 200 million people would become sick and another 35 million people would die from the disease (WHO, 2005). Tuberculosis is a major public health problem in Nigeria with an estimated prevalence of 616 cases per 100,000 (WHO, 2008). Nigeria ranks first in Africa and fourth among the 22 high TB burden countries in the world (WHO, 2008). No fewer than 460,000 cases of tuberculosis are reported annually in Nigeria (WHO, 2008). The co-infection of pulmonary tuberculosis with human immune deficiency virus and acquired immune deficiency syndrome (HIV/AIDS) has in the recent past compounded the epidemiology, clinical outcome, diagnosis and treatment of the disease worldwide (CDC, 1995). Previous study has shown that anaemia, raised erythrocyte sedimentation rate (ESR), high peripheral leucocyte count and neutrophilia are the most common haematological manifestations associated with PTB (Devi et al, 2003). Another study carried out in Kano, Northern Nigeria, reported mild anaemia, and raised ESR, leucocytosis, neutrophilia with toxic granulation, thrombocytosis, occasional stickiness of platelets and monocytosis (Nwankwo et al., 2005). In Benin, Southern Nigeria, a study showed significant increase in plasma viscosity and fibrinogen levels and a decrease in platelet count, total white cell count and packed cell volume when compared with values for apparently healthy subjects (Awodu et al., 2007). It is our aim to study the pattern of some haematological parameters in PTB infected subjects in Calabar, Nigeria. It is believed that the findings of this study will be useful as indicators of disease progression, cardiovascular risk factors and response to therapy in pulmonary tuberculosis.

\section{SUBJECTS, MATERIALS AND METHODOLOGY Study area and population}

A total of one hundred (100) male and female pulmonary tuberculosis patients aged between ten to seventy-one (10-71) years, attending the Endemic Diseases Clinic, Department of Community Medicine, University of Calabar Teaching Hospital and Dr Lawrence Henshaw Memorial Specialist Hospital, Calabar, Nigeria were selected for the study. Ethical approval was obtained from the Research Ethics Committee of Cross River State Ministry of Health which covered both hospitals. The bio-data and medical history of these patients were obtained through questionnaire, while permission was sought to obtain information from the case notes of those who could not fill questionnaire. Subjects who were diagnosed as PTB patients based on the presence of the acid fast bacilli (AFB) in their sputum smear were recruited into the study. The HIV status of the patients was determined using two rapid HIV test methods. One hundred (100) age and gender-matched apparently healthy individuals who tested negative for AFB in their sputum smear and HIV sero-negative were used as control subjects in this study. They were selected from staff of Dr Lawrence Henshaw Memorial Hospital who were also residents of Calabar South Local Government Area. Informed consent was sought and obtained from all participants.

\section{Sample collection and processing}

Five millilitres $(5 \mathrm{ml})$ of blood was collected under aseptic conditions with minimal stasis from each subject, $2 \mathrm{~m}$ was in a plain sample bottle while $3 \mathrm{ml}$ was added to ethylene diamine tetra acetic acid (EDTA) anticoagulant with a concentration of $1.5 \mathrm{mg} / \mathrm{ml}$ in a sample bottle for determination of packed cell volume (PCV), haemoglobin ( $\mathrm{Hb})$ concentration, mean cell volume (MCV), mean cell haemoglobin $(\mathrm{MCH}$,$) mean$ cell haemoglobin concentration ( $\mathrm{MCHC}$ ), white blood cell (WBC) and platelet counts, using PCE 210 version 5.10 (ERMA INC. Tokyo) automatic blood cell counter, and erythrocyte sedimentation rate (ESR) by Westergren technique (William et al.,1993). The remaining blood sample $(2 \mathrm{ml})$ was separated by centrifugation and the serum used for HIV screening using two rapid HIV test methods, Determine ${ }^{\text {TM }}$ HIV $1 / 2$ (Alere Medical Co. Ltd., Japan) and VIKIA ${ }^{\circledR}$ HIV $1 / 2$ (bioMérieux SA, France). The data generated from this work was subjected to student t-test analysis and oneway analysis of variance. A two tailed P-value of $<0.05$ was considered statistically significant.

\section{Principle of Determine ${ }^{\mathrm{TM}}$ HIV $1 / 2$ Test \\ Alere Determine ${ }^{\mathrm{TM}}$ HIV-1/2 is an} immunochromatographic test for qualitative detection of antibodies to HIV-1 and HIV-2. Sample is added to the sample pad. As the sample migrates through the conjugate pad, it reconstitutes and mixes with the selenium colloid-antigen conjugate. This mixture continues to migrate through the solid phase to the immobilized recombinant antigens and synthetic peptides at the patient window site.

If antibodies to HIV-1 and/or HIV-2 are present in the sample, the antibodies bind to the antigen-selenium colloid and to the antigen at the patient window, forming a red line at the patient window site. If antibodies to HIV1 and/or HIV-2 are absent, the antigen-selenium colloid flows past the patient window, and no red line is formed at the patient window site. To insure assay validity, a procedural control bar is incorporated in the assay device (Weniger et al., 1994).

\section{Principle of VIKIA ${ }^{\circledR}$ HIV $1 / 2$ Test}

VIKIA HIV $1 / 2$ is a visually read rapid test, based on the immunochromatography technique (ICT or lateral flow) for the qualitative detection of serumantibodies to HIV-1 and HIV-2 in human serum, plasma or whole blood. The test consists of a plastic 
device containing a chromatography membrane to which are fixed: in the test region ("T"), synthetic peptides specific for HIV-1 (gp41 of group M and Group O), and HIV-2 (gp36); in the control region (C), two colour indicators and a test strip impregnated with a conjugate consisting of a mixture of synthetic peptides specific for HIV-1 and HIV-2, coupled to blue dyed polystyrene microspheres. The sample is added to the sample well and migrates by capillarity along the membrane.

If the sample contains anti-HIV antibodies, they form an antigen-antibody complex with the peptides specific to this virus, present on the blue-dyed polystyrene microspheres. The antigen-antibody complexes migrate along the membrane and bind to the synthetic peptides immobilized on the nitrocellulose membrane. This is revealed by a blue line in the test region "T". The test is validated if the colour of the control line in region " $C$ " changes from blue to pink/red. If this line does not change colour, the test is invalid (Sharp et al., 1994).

\section{RESULTS}

In this study, some haematological parameters of pulmonary tuberculosis patients in Calabar were investigated. The tests performed included measurement of packed cell volume, haemoglobin concentration, mean cell haemoglobin, mean cell haemoglobin concentration, mean cell volume, erythrocyte sedimentation rate, white blood cell and platelet counts. The results obtained were compared with apparently healthy subjects (controls).

Table 1 shows the mean values of the various parameters that were analysed. The mean values obtained for HB, PCV, MCH and Platelets of PTB patients were significantly lower $(p<0.05)$ than values obtained for control subjects. While the MCV and erythrocyte sedimentation rate of PTB patients were significantly higher $(p<0.05)$ than those of control subjects. The WBC counts for both groups of subjects did not show any significant difference.

TABLE 1: MEAN \pm SD VALUE OF HEMATOLOGICAL PARAMETERS IN BOTH TEST SUBJECTS AND
\begin{tabular}{lccc}
\multicolumn{4}{c}{ CONTROLS OF THE STUDY } \\
\hline Parameters & TB Patient & Control & P-value \\
\hline PCV $(\mathrm{L} / \mathrm{L})$ & $0.25 \pm 0.05$ & $0.39 \pm 0.04$ & 0.05 \\
ESR $(\mathrm{mm} / \mathrm{hr})$ & $104.2 \pm 32.4$ & $34 \pm 1.7$ & 0.05 \\
Platelet count $\left(\times 10^{9} / \mathrm{L}\right)$ & $111.9 \pm 31.8$ & $218.2 \pm 53.3$ & 0.05 \\
WBC $\left(\mathrm{x} 10^{9} / \mathrm{L}\right)$ & $5.9 \pm 2.6$ & $6.3 \pm 1.7$ & 0.05 \\
MCH $(\mathrm{pg})$ & $26.6 \pm 3.1$ & $27.8 \pm 2.3$ & 0.05 \\
MCV $(\mathrm{fl})$ & $79.8 \pm 7.84$ & $77.06 \pm 4.8$ & 0.05 \\
$\mathrm{Hb}(\mathrm{g} / \mathrm{dl})$ & $8.5 \pm 3.4$ & $14.3 \pm 2.0$ & 0.05 \\
\hline
\end{tabular}

The haematological parameters of PTB patients based on age distribution is shown in Table 2 . The age group $10-30$ years had the highest prevalence rate of infection (60\%). The mean values of PCV, ESR obtained were significantly higher in age group 31-50 years while age group 51-71 years had WBC value that was significantly lower than those of other age groups. The differences in platelets, MCV and $\mathrm{MCH}$ values were not statistically significant.

TABLE 2: HEMATOLOGICAL PARAMETERS OF TB PATIENTS BASED ON AGE DISTRIBUTION

\begin{tabular}{lccccccc}
\hline $\begin{array}{l}\text { Age } \\
\text { (yrs) }\end{array}$ & $\begin{array}{c}\text { Pop. } \\
\text { Affected(\%) }\end{array}$ & $\begin{array}{c}\text { PCV } \\
\text { (L/L) }\end{array}$ & $\begin{array}{c}\text { ESR } \\
\text { (mm/hr) }\end{array}$ & $\begin{array}{c}\text { Platelet } \\
\text { count } \\
(\mathbf{x 1 0} / \mathbf{L})\end{array}$ & $\begin{array}{c}\text { WBC } \\
\text { count } \\
(\mathbf{x 1 0} / \mathbf{L})\end{array}$ & $\begin{array}{c}\text { MCH } \\
\mathbf{( p g )}\end{array}$ & $\begin{array}{c}\text { MCV } \\
\text { (fl) }\end{array}$ \\
\hline $10-30$ & 60 & $0.25 \pm 0.15$ & $105 \pm 66.7$ & $109 \pm 68.7$ & $6.18 \pm 3.9$ & $27.9 \pm 2.2$ & $80.1 \pm 1.4$ \\
$31-50$ & 30 & $0.31 \pm 0.08$ & $133 \pm 34.6$ & $143 \pm 37.2$ & $7.5 \pm 1.9$ & $26.8 \pm 3.6$ & $78 \pm 2.5$ \\
$51-70$ & 10 & $0.24 \pm 0.02$ & $112 \pm 0.7$ & $115 \pm 7.4$ & $4.1 \pm 12.3$ & $28.7 \pm 1.5$ & $78 \pm 15$ \\
P-value & 0.05 & 0.05 & 0.05 & 0.05 & 0.05 & 0.05 & 0.05 \\
\hline
\end{tabular}

Table 3 shows haematological parameters of PTB patients based on gender. It was shown that males were more affected than females. The mean values of
PCV, ESR, MCV, MCH, WBC and Platelets counts obtained in both males and females were not significantly different. 
TABLE 3: HEMATOLOGICAL PARAMETERS OF TB PATIENTS BASED ON GENDER

\begin{tabular}{lccccccc}
\hline Gender & $\begin{array}{c}\text { Pop. } \\
\text { Affected(\%) }\end{array}$ & $\begin{array}{c}\text { PCV } \\
\text { (L/L) }\end{array}$ & $\begin{array}{c}\text { ESR } \\
(\mathbf{m m} / \mathbf{h r})\end{array}$ & $\begin{array}{c}\text { Platelet } \\
\text { count } \\
(\mathbf{\times 1 0} / \mathbf{L})\end{array}$ & $\begin{array}{c}\text { WBC } \\
\text { count } \\
(\mathbf{x 1 0} / \mathbf{L})\end{array}$ & $\begin{array}{c}\text { MCH } \\
\text { (pg) }\end{array}$ & $\begin{array}{c}\text { MCV } \\
\text { (fl) }\end{array}$ \\
\hline Males & 62 & $0.25 \pm 0.15$ & $104 \pm 63.8$ & $109 \pm 66.4$ & $5.8 \pm 3.5$ & $27.9 \pm 3.2$ & $80.2 \pm 2.0$ \\
Females & 38 & $0.25 \pm 0.09$ & $107 \pm 39.2$ & $118 \pm 43.1$ & $6.3 \pm 2.3$ & $28.7 \pm 3.1$ & $79.3 \pm 3.5$ \\
P-value & 0.05 & 0.05 & 0.05 & 0.05 & 0.05 & 0.05 & 0.05 \\
\hline
\end{tabular}

The haematological variables of 31 HIV seropositive pulmonary tuberculosis patients compared with 69 counterparts who were sero-negative for HIV infection is shown in Table 4. Apart from the WBC and Platelets counts which did not change significantly, the
PCV, $\mathrm{Hb}$ concentration (decreased), $\mathrm{MCV}, \mathrm{MCH}$, and ESR (increased) of the sero-positive patients changed significantly $(p<0.05)$ when compared with values for sero-negative patients.

TABLE 4: SOME HAEMATOLOGICAL PARAMETERS OF PULMONARY TUBERCULOSIS PATIENTS COINFECTED WITH HIV

\begin{tabular}{|c|c|c|c|}
\hline Parameters & $\begin{array}{l}\text { Sero-positive } \\
\quad(n=31)\end{array}$ & $\begin{array}{l}\text { Sero-negative } \\
\quad(n=69)\end{array}$ & P-value \\
\hline $\begin{array}{l}\text { PCV (L/L) } \\
\text { ESR (mm/hr) } \\
\text { Platelets }\left(\times 10^{9} / \mathrm{L}\right) \\
\text { WBC (x109 } / \mathrm{L}) \\
\text { MCH (pg) } \\
\text { MCV (fl) } \\
\text { Hb (g/dl) }\end{array}$ & $\begin{array}{c}0.26 \pm 0.14 \\
89.2 \pm 32.4 \\
181.9 \pm 31.8 \\
5.3 \pm 2.6 \\
29.6 \pm 3.1 \\
79.8 \pm 7.84 \\
9.0 \pm 1.4\end{array}$ & $\begin{array}{c}0.33 \pm 0.08 \\
34.0 \pm 31.7 \\
158.2 \pm 53.3 \\
5.6 \pm 1.7 \\
27.8 \pm 2.3 \\
77.06 \pm 4.8 \\
11.1 \pm 1.2\end{array}$ & $\begin{array}{l}0.05 \\
0.05 \\
0.05 \\
0.05 \\
0.05 \\
0.05 \\
0.05 \\
\end{array}$ \\
\hline
\end{tabular}

\section{DISCUSSION}

Pulmonary tuberculosis (PTB) is a major infectious disease with very high incidence in developing countries and this is expected to rise with the incidence of HIV infection. Based on the results obtained from this study, the mean values of haemoglobin concentration, packed cell volume, mean cell haemoglobin and platelets counts of pulmonary tuberculosis patients $(8.5$ $\pm 3.4 \mathrm{~g} / \mathrm{dl}, 0.25 \pm 0.05 \mathrm{~L} / \mathrm{L}, 26.6 \pm 3.1 \mathrm{pg}$ and $111.9 \pm 31.8 \mathrm{x}$ $\left.10^{9} / \mathrm{L}\right)$ were significantly lower $(\mathrm{p}<0.05)$ than those of control subjects $(14.3 \pm 2.0 \mathrm{~g} / \mathrm{dl}, 0.39 \pm 0.04 \mathrm{~L} / \mathrm{L}, 27.8 \pm$ 2.3pg and $\left.218.2 \pm 53.3 \times 10^{9} / \mathrm{L}\right)$, the mean cell volume was $(79.8 \pm 7.84 \mathrm{fl})$ significantly higher than that of control subjects $(77.06 \pm 4.8 \mathrm{fl})$. This was a reverse trend but could not be investigated further as it was beyond the scope of the study. Some studies (Erster et al., 1980; Morris et al., 1989; Ebrahim et al., 1995; Ajayi et al., 2005; Lee et al., 2006; Miah et al., 2007) reported significant decreases in these haematological parameters of PTB patients and this agrees with the results of our study. Anaemia, defined as a reduction in haemoglobin concentration and by implication PCV, alongside the absolute values ( $\mathrm{MCV}, \mathrm{MCH}$ and $\mathrm{MCHC}$ ), has been reported in some studies (Robson, 1996; Turken et al., 2002). This has been classified as normocytic normochromic with all the characteristics of anaemia of chronic disorders (Nwankwo et al., 2005). Pulmonary tuberculosis being a chronic ailment, has a long term effect on the haemopoietic system through bone marrow depression leading to a decrease in erythropoeisis and resulting in the lower values in the test subjects.

The mean Erythrocyte Sedimentation Rate (ESR) of the TB subjects $(104.2 \pm 32.4 \mathrm{~mm} / \mathrm{hr})$ in this study was significantly higher when compared with that of control subjects $(34.0 \pm 1.7 \mathrm{~mm} / \mathrm{hr})$. This could be as a result of inflammation and degenerative changes (these are general features of PTB) due to increase in production of acute phase protein, reduced albumin, often observed in chronic infections and release of proteins by the causative organism (M.tuberculosis) into the circulation (Willey et al., 2008). These findings are supported by different studies specifying higher ESR values for PTB patients (Stenius-Aarniala and Tukianinen, 1979; Chia and Machin, 1979; Morris et al., 
1989; Akintunde et al., 1995; Olaniyi and Aken'ova, 2003; Ajayi et al., 2005; Awodu et al., 2007; Ibeneme et al., 2009).

Furthermore, mean platelet count of test subjects $\left(111.9 \pm 31.8 \times 10^{9} / \mathrm{L}\right)$ in the study showed significantly lower value when compared with that of control subjects

$\left(218.2 \pm 53.3 \times 10^{9} / \mathrm{L}\right)$ (thrombocytopenia - platelet < $150 \times 10^{9} / \mathrm{L}$ ) and this could be as a result of the effect of the anti-tuberculosis treatment in the test subjects. This is in agreement with previous work done by (Martens et al., 1995; Al-Majed et al., 1995).

In this study, the mean white blood cell count of PTB patients was $5.9 \pm 2.6 \times 10^{9} / \mathrm{L}$ and this showed no significant difference with control value $(6.3 \pm 1.7 \times$ $\left.10^{9} / \mathrm{L}\right)$. This result agrees with the mean white blood cell count $\left(5.6 \pm 0.4 \times 10^{9} / \mathrm{L}\right)$ obtained in the same locality (Olaniyi and Aken'ova, 2003; Ibeneme et al., 2009) but disagrees with leucocytosis that has been reported previously (Robson et al., 1996). It is also at variance with another report of decreased white cell count in PTB patients (Awodu et al., 2007). Although the authors did not state whether their subjects were on treatment or not, this could have affected their results. However, most of the PTB patients enrolled in this study were undergoing anti-tuberculosis treatment and this may account for the disparity in result.

Of the 100 pulmonary tuberculosis patients enrolled in the study, 31 were HIV sero-positive giving a 31 per cent prevalence rate while 69 were HIV seronegative. The 31 per cent prevalence rate of HIV coinfection observed in this study is similar to that reported by the National Tuberculosis and Leprosy Control Programme of Nigeria (NTBLCP, 2008). The mean $\mathrm{Hb}$, and PCV values of the sero-positive patients were significantly lower $(p<0.05)$ than those obtained for the sero-negative patients while the mean ESR of the seropositive patients was significantly higher $(p<0.05)$ than that of the sero-negative patients. These differences may be due to the impact of HIV infection on the alveolar macrophages thereby enhancing the pathogenesis of pulmonary tuberculosis and aggravating anaemia. The mean values obtained for white cell and platelet counts, mean cell volume, and mean cell haemoglobin of the sero-positive patients were similar $(p>0.05)$ to those of the sero-negative patients. kpDifferential white cell count was not performed in this study.

\section{CONCLUSION}

This study has established significant changes in the haematological variables studied in pulmonary tuberculosis patients in Calabar. They had low PCV, $\mathrm{MCH}, \mathrm{Hb}$ and Platelets count, high ESR and MCV values. A higher frequency of pulmonary tuberculosis was revealed within the age group $10-30$, followed by $31-50$ and $51-71$ as the least group. The study also pointed out that males were more infected than females while HIV co-infection affected the $\mathrm{Hb}, \mathrm{PCV}$ and ESR values significantly. Knowledge of this haematological picture will enhance the overall management of pulmonary tuberculosis patients with regard to monitoring disease progression and response to antimicrobial chemotherapy as they will serve as useful indicators for treatment success or failure.

\section{ACKNOWLEDGEMENTS}

The authors wish to acknowledge the assistance received from Mrs. Naomi Ernest of the University of Calabar Teaching Hospital and Mr. Esu Asuquo of the Dr. Lawrence Henshaw Memorial Hospital Calabar in processing the samples for this work. We are also grateful to the subjects for accepting to be part of this study.

\section{REFERENCES}

Ajayi, O., Famodu, A., Onyemairo, J., Iyere, C., Onaghise, V and Adogun, C., 2005. Haemorrheological alterations in Nigerian pulmonary tuberculosis patients. $15^{\text {th }}$ European Congress of Clinical Microbiology and Infectious Diseases, Copenhagen, Denmark.

Akintunde, E. O., Shokunbi, W. A and Adekunle, C. O., 1995. Leucocyte Count, Platelet Count and Erythrocyte Sedimentation rate in pulmonary tuberculosis. Afr. J. Med. Sci. (24): 131-134.

Al-Majed, S. A., Al-Momen, A. K., Al-Kassini, F. A., AlZeer, A., Kambal, A. M and Baagi, L. H., 1995. Tuberculosis presenting as Immune thrombocytopenic purpura. Acta Hematol. (94): 135-138.

Awodu, O. A., Ajayi, I. O and Famodu, A. A., 2007. Hemorrheological variables in Nigerian Pulmonary tuberculosis patients undergoing therapy. Clin. Hemorrheol. Microcircular (36): 267-275.

Centers for Disease Control and Prevention., 2010. Questions and Answers about Tuberculosis, http://www.cdc.gov/tb/publications/faqs/pdfs/qa. pdf. Accessed May 15,2012.

Centers for Disease Control and Prevention., 2007. Controlling tuberculosis in correctional facilities. Atlanta: Department of Human Services and Centres for Disease Control and Prevention.

Chia, Y. C and Machin, S. J., 1979. Case Report: tuberculosis and severe thrombocytopenia. $\mathrm{Br}$. J. Clin. Pract. (33): 55-56.

Devi, U., Mohan, R. C., Srivastava, V. K., Rath, P. K and

Das, B. S., 2003. Effect of iron supplementation on mild to moderate anaemia in pulmonary tuberculosis. Br. J. Nutri. 9, (3): 541-550.

Ebrahim, O., Folb, P. I and Robson, J. P., 1995. Blunted Erythropoietin response to anaemia in tuberculosis. Eur. J. Hematol. (55): 251-254.

Edward, D. C and Kirk-Patrick, H. 1986. Immunology of Mycobacterial Diseases. American Review of Respiratory Disease (134): 1002-1021. 
Erster, A. J., Caro, J., Miller, O and Silver, R., 1980. Plasma Erythropoietin in health and disease. Ann. Clin. Lab. Sci. (10): 250-257.

Fraser, R. S., 1993. Pulmonary aspergillosis: Pathologic and pathogenic features. Pathology Annual (28): 231-277.

Ibeneme, E. O., Asuquo, A. E and Abia-Bassey, L. N., 2009. Prevalence of pulmonary tuberculosis and HIV coinfection among prisoners in Calabar, Nigeria. Mary Slessor Journal of Medicine 9, (2): 10-18.

Iseman, M. C., 2008. Tuberculosis. In: Goldman L. (Editor) Cecil Medicine. $23^{\text {rd }}$ ed. Philadelphia, Saunders, Elservier, 145-154.

Iseman, M. C., 2000. A clinician's guide to tuberculosis. Philadelphia, Lippincot, Williams and Wilkins,

Kabir, M., Obasanya, O and Vander-Grinten, E., 2010. National Tuberculosis and Leprosy Control Programme (NTBLCP). Worker's manual revised. $5^{\text {th }}$ ed.

Lee, S. W., Kang, Y. A., Yoon, Y. S., Um, S. W and Lee,

S. M., 2006. The prevalence and evaluation of anaemia associated with tuberculosis. J. Korean Med. Sci. (21): 1028-1032.

Martens, G. A., Paul, W and Benatar, S., 1995. Milliary tuberculosis: Rapid diagnosis, haematologic abnormalities and outcome in 109 treated adults. J. Clin. Invest. (89): 291-296.

Miah, M. A., Chowhury, U. A., Ahmed, N., Shafique, M and Islam, N., 2007. Simultaneous occurrence and multiple types of cutaneous tuberculosis with internal organ tuberculosis (PTB). Mymensingn Med. J. (16): 108-112.

Morris, C. D. W., 1989. The radiography, haematological and biochemical changes in severe pulmonary tuberculosis. Q. J. Med. (73): 1151-1159.

National Tuberculosis and Leprosy Control Programme: Federal Ministry of Health, Nigeria, 2008. Workers Manual $5^{\text {th }}$ ed.

Nwankwo, E. K., Kwarru, A., Ofulu, A and Babashani, M., 2005. Haematological changes in tuberculosis in Kano, Nigeria. Journal of Medical Lab. Science $14,(2): 23-28$

Olaniyi, J. A and Aken'ova, Y. A., 2003. Bone Marrow findings in patients with tuberculosis. Afr. J. Med. Sci. (32): 155-157.

Robson, S. C., White, N. W., Aronson, I., Woolgar, R., Goodman, $\mathrm{H}$ and Jacobs, P., 1996. Acute-phase response and the hypercoagulable state in pulmonary tuberculosis. British Journal of Haematology (93): 943-949.
Sharp, P. M., Robertson, D. L., Gao, F and Hahn, B. H., 1994. Origins and diversity of Human immunodeficiency viruses. AIDS 8, (1): S27-S42.

Snider, D. E., Ravighone, M and Kochi, A., 1994. Global burden of Tuberculosis. In B. Bloom (Ed.) Tuberculosis: Pathogenesis, prevention and control. Materials Park: American Society for Microbiology Press.

Stenius-Aarniala, B and Tukianinen, P., 1979. Milliary tuberculosis. Acta Med. Scand. (206): 417-422.

Turken, O., Kunter, E and Sezer, M., 2002. Haemostatic changes in active pulmonary tuberculosis. International Journal of Tuberculosis and Lung Disease 6, (10): 927-932.

Weniger, B. G., Takebe, $Y$ and Ou, C. Y., 1994. The molecular epidemiology if HIV in Asia. AIDS, 8, (2): S13-S28.

WHO Report., 2005. Tuberculosis Fact Sheet. http://www.emro.who.int/entity/tb.

WHO Report., 2008. Global tuberculosis control: Surveillance, planning and financing.

WHO Report., 2010. Worldwide prevalence of Tuberculosis. http://www.cureresearch.com/t/tub erculosis/prevalence. Accessed September 29, 2012.

Willey, J. M., Sherwood, L. M and Woolverton, C. J. (Eds), 2008. Mycobacterium tuberculosis infections. Prescott, Harley, \& Klein's Microbiology $7^{\text {th }}$ edition. (pp. 951-955) New York: McGraw Hill Companies.

William, J. W., Benller, E., Esley, A. J and Lichman, N., 1993. International Council for Standardization in Haematology. $3^{\text {rd }}$ ed. McGraw Hill Books, Singapore, 1670-1678. 